\title{
PENGARUH GAYA BELAJAR SISWA TERHADAP HASIL BELAJAR SISWA MATA PELAJARAN IPS SEMESTER GENAP DI MTS FATHUS SALAFI MANGARAN KABUPATEN SITUBONDO
}

\author{
Muh. Fais Fathoni ${ }^{1}$ Dassucik $^{2}$, Ahmad Hafas Rasyidi ${ }^{3}$ \\ ${ }^{1}$ Mahasiswa Prodi Pendidikan Ekonomi STKIP PGRI Situbondo \\ ${ }^{2,3}$ Dosen Pendidikan Ekonomi STKIP PGRI Situbondo \\ Email: tolekdiningrat@gmail.com
}

\begin{abstract}
ABSTRAK.
Pada dasarnya pendidikan merupakan faktor pendukung keberhasilan seseorang dalam menjalani kehidupan bermasyarakat. Tujuan dari penelitian ini adalah Untuk mengetahui ada tidaknya pengaruh gaya belajar siswa terhadap hasil belajar siswa mata pelajaran IPS semester genap di MTs Fathus Salafi Mangaran Kabupaten Situbondo tahun pelajaran 2020/2021. Dari hasil penelitian yang diperoleh dengan menggunakan rumus analisis variansi garis regresi menghasilkan Ry $(1,2)$ empiric sebesar 0,60017. Yang apabila dikonsultasikan dengan $\mathrm{r}$ table dengan $\mathrm{N}$ sebanyak 100 responden dan taraf signifikansi 5\% diperoleh 0,195 . perhitungan tersebut dimaksudkan untuk membuktikan hipotesa kerja mayor dengan menggukan uji signifikansi. Dari hasil perhitungan analisis variansi garis regresi diperoleh $F_{\text {reg }}$ sebesar 27,30494. Dan apabila dikonsultasikan dengan $\mathrm{F}$ tabel untuk $\mathrm{db}=2$ dan $\mathrm{db}=97$ dengan taraf signifikansi 5\% diperoleh 3,0902 Dengan demikian dari hasil perhitungan tersebut menunjukkan $\mathrm{F}$ reg lebih besar dari $\mathrm{F}$ tabel. Berdasarkan analisa data dimuka, maka hipotesa kerja mayor yang berbunyi "Ada pengaruh gaya belajar siswa terhadap hasil belajar siswa diterima. Selanjutnya dalam efektifitas garis regresi dipreroleh sebesar 36,01972\%. Ini berarti sumbangan efektif dari keseluruhan predictor hasil belajar siswa memberikan sumbangan sebesar 36,01972\% sedangkan predictor lain yang tidak diteliti memberikan sumbangan sebesar 63,98828\%. Sumbangan Efektif (SE) predictor $\left(\mathrm{X}_{1}\right)$ gaya belajar modalitas terhadap kriterium (Y) hasil belajar siswa 17,02444\%, Sumbangan Efektif (SE) predictor $\left(\mathrm{X}_{2}\right)$ gaya belajar dominasi otak terhadap kriterium $(\mathrm{Y})$ hasil belajar siswa 18,99528\%, ini menunjukan bahwa gaya belajar dominasi otak lebih berpengaruh terhadap hasil belajar siswa dibandingkan gaya belajar modalitas.
\end{abstract}

\section{Kata Kunci: Gaya Belajar, Hasil Belajar}

\section{PENDAHULUAN}

Dalam konteks pembaharuan pendidikan ada 3 (tiga) isu utama yang perlu disoroti, yaitu pembaharuan kurikulum, peningkatan kualitas pembelajaran, dan efektifitas metode pembelajaran (Nurhadi dan Senduk, 2013:1). 
Manurut Djamarah (2012:13) belajar adalah serangkaian kegiatan jiwa raga yang memperoleh satu perubahan tingkah laku sebagai hasil dari pengalaman individu dalam interaksi dari lingkungannya yang menyangkut kognitif, afektif dan psikomotorik. Hakim menyatakan bahwa belajar adalah suatu proses perubahan di dalam kepribadian manusia dan perubahan tersebut ditempatkan dalam bentuk peningkatan kualitas, dengan kualitas tingkah laku seperti peningkatan kecakapan, pengetahuan, sikap, kebiasaan, pemahaman, keterampilan, daya pikir dan kemampuan lainnya (2011:5).

Menurut Bobbi (2010:110) gaya belajar adalah cara yang konsisten yang dilakukan oleh seorang murid dalam mengungkap stimulus atau informasi, cara mengingat, berpikir, dan memecahkan masalah. Gaya belajar merupakan kunci untuk mengembangkan kinerja dalam situasi-situasi antar pribadi.

Menurut Rina (dalam Bobbi, 2010:110) gaya belajar adalah kombinasi dari bagaimana cara ia menyerap dan kemudian mengatur serta mengolah informasi. Gaya belajar mencakup faktor-faktor fisik, emosional, sosiologis, dan lingkungan. Gaya belajar pada umumnya ada dua kategori yang pertama bagaimana kita menyerap informasi dengan mudah (modalitas), dan kedua cara kita mengatur serta mengolah informasi (dominasi otak).

Modalitas merupakan cara termudah untuk menyerap informasi. Modalitas meliputi visual, auditorial, dan kinestetik (V-A-K). Orang visual belajar melalui apa yang mereka lihat. Orang auditorial belajar melakukan melalui apa yang mereka dengar. Dan orang kinestetik belajar lewat sentuhan dan gerakan.

Dominasi otak merupakan cara mengatur dan mengolah informasi. Dominasi otak meliputi persepsi dan pengaturan. Persepsi adalah cara menerima informasi atau menangkap sesuatu hal, secara pribadi atau individu. Sedangkan pengaturan adalah cara mengatur dan menggunakan informasi yang dipersepsikan.

Akhir-akhir ini timbul pemikiran baru yaitu bahwa mengajar itu harus memperlihatkan gaya belajar atau learning style, siswa akan bereaksi dan menggunakan perangsang-perangsang yang diterimanya dalam proses belajar.

Pada prakteknya penerapan proses belajar mengajar kurang mendorong pada pencapaian hasil belajar siswa. Dua faktor penyebab hasil belajar tidak berkembang selama pendidikan adalah kurikulum yang umumnya dirancang dengan target materi yang luas sehingga guru lebih terfokus pada penyelesaian 
materi dan kurangnya pemahaman guru tentang metode pengajaran yang dapat meningkatkan hasil belajar siswa.

Informasi tentang adanya gaya belajar yang berbeda-beda mempunyai pengaruh atas kurikulum, administrasi dan proses belajar mengajar dengan baik, karena masalah itu dianggap sulit dan membutuhkan waktu yang cukup lama. Selain itu juga membutuhkan biaya yang tidak sedikit. Sedangkan siswa memiliki gaya belajar sendiri untuk menyerap, mengatur serta mengolah informasi (bahan/ materi yang diajarkan). Disisi lain siswa juga membutuhkan suatu perubahan dalam proses belajar mengajar karena siswa merasa jenuh dengan adanya pembelajaran yang sama atau tetap. Meskipun demikian tidak sedikit siswa yang mendapatkan nilai yang baik dan bahkan lulus dengan nilai yang baik pula. Akan tetapi kenyatakan di atas menyatakan bahwa tidak selamanya gaya mengajar yang berpengaruh terhadap hasil belajar siswa.

Dengan latar belakang di atas maka timbul suatu ide untuk mengadakan suatu penelitian yang berjudul "Pengaruh gaya belajar siswa terhadap hasil belajar siswa mata pelajaran IPS semester genap di MTs Fathus Salafi Mangaran Kabupaten Situbondo tahun pelajaran 2020/2021".

\section{METODE PENELITIAN}

Penelitian ini merupakan penelitian jenis penelitian kuantitatif. Dalam penelitian kuantitatif, masalah yang dibawa oleh peneliti sudah jelas (Sugiyono, 2016:30). Dalam Penelitian ini peneliti menggunakan rancangan penelitian ex post facto. Penelitian disebut ex post facto karena para peneliti berhubungan dengan variabel yang telah terjadi dan mereka tidak perlu memberikan perlakuan terhadap variabel yang diteliti. Teknik penentuan lokasi yang digunakan oleh peneliti adalah purposive sampling area. Penelitian ini dilakukan di MTs Fathus Salafi Mangaran. Adapun populasi dalam penelitian adalah 100 siswa kelas VII, VIII dan IX semester genap dengan teknik penentuan responden menggunakan proporsional random sampling. Sedangkan analisis data dalam penelitian ini dilakukan dengan uji regresi berganda.

\section{HASIL DAN PEMBAHASAN}

\section{Persamaan Garis Regresi}

$$
\begin{aligned}
& \mathrm{Y}=\mathrm{a}_{1}\left(\mathrm{X}_{1}-\mathrm{X}_{1}\right)+\mathrm{a}_{2}\left(\mathrm{X}_{2}-\mathrm{X}_{2} \overline{)}+\mathrm{Y}-\right. \\
& \mathrm{Y}=1,23849\left(\mathrm{X}_{1}-23,75\right)+1,48082\left(\mathrm{X}_{2}-23,42\right)+78,90
\end{aligned}
$$




$$
\begin{aligned}
& Y=1,23849 X_{1}-29,41414+1,48082 X_{2}-34,68080+78,90 \\
& Y=1,23849 X_{1}+1,48082 X_{2}+14,80506
\end{aligned}
$$

Dari perhitungan di atas dapat dituliskan persamaan garis regresinya untuk variabel bebas terhadap variabel terikatnya adalah:

$$
Y=1,23849 X_{1}+1,48082 X_{2}+14,80506
$$

Dari perhitungan di atas dapat dituliskan persamaan garis regresinya untuk variabel bebas terhadap variabel terikatnya adalah :

\section{a. Konstanta}

Konstanta sebesar 14,80 mempunyai arti adanya pengaruh yang positif terhadap hasil belajar siswa yaitu gaya belajar siswa tetap atau konstan, akan mempengaruhi hasil belajar siswa sebesar 14,80 dengan variabel pengganggu yang tidak tidak diteliti.

\section{b. Koefisien Regresi Gaya Belajar Modalitas $\left(\mathbf{X}_{1}\right)$}

Koefisien regresi gaya belajar modalitas $\left(\mathrm{X}_{1}\right)$ menunjukkan besarnya perubahan variabel hasil belajar siswa (Y) sehubungan dengan perubahan variabel gaya belajar modalitas dengan asumsi variabel gaya belajar dominasi otak tetap atau konstan. Perubahan yang terjadi bersifat positif atau searah, artinya apabila salah satu variabel mengalami kenaikan, akan mengakibatkan kenaikan variabel lainnya. Apabila terjadi perubahan variabel gaya belajar modalitas $\left(\mathrm{X}_{1}\right)$ sebesar $1 \%$ dengan anggapan variabel gaya belajar dominasi otak $\left(\mathrm{X}_{2}\right)$ sama dengan nol menyebabkan perubahan variabel hasil belajar siswa (Y) sebesar 1,23849.

\section{c. Koefisien Regresi Gaya Belajar Dominasi Otak $\left(\mathbf{X}_{2}\right)$}

Koefisiensi regresi gaya belajar dominasi otak $\left(\mathrm{X}_{2}\right)$ menunjukkan besarnya perubahan variabel hasil belajar siswa (Y) sehubungan dengan perubahan variabel gaya belajar dominasi otak $\left(\mathrm{X}_{2}\right)$ dengan asumsi variabel gaya belajar modalitas $\left(\mathrm{X}_{1}\right)$ konstan. Perubahan yang terjadi bersifat positif atau searah, artinya apabila salah satu variabel mengalami kenaikan, akan menyebabkan kenaikan variabel lainnya. Apabila terjadi perubahan gaya belajar dominasi otak $\left(\mathrm{X}_{2}\right)$ sebesar $1 \%$ dengan anggapan variabel gaya belajar modalitas $\left(\mathrm{X}_{1}\right)$ sama dengan nol menyebabkan perubahan variabel hasil belajar siswa sebesar $\mathbf{1 , 4 8 0 8 2}$. 


\section{Koefisien Korelasi}

Untuk mengetahui sejauh mana pengaruh antara gaya belajar siswa terhadap hasil belajar dilakukan analisis data dan pengujian hipotesis mayor dengan menghitung korelasi antara $\mathrm{X}_{1}$ dan $\mathrm{X}_{2}$ secara serentak dengan variabel $\mathrm{Y}$.

$$
\begin{aligned}
\mathrm{R}_{\mathrm{y}(1,2)} & =\sqrt{\frac{a_{1} \sum x_{1} y+a_{2} \sum x_{2} y}{\sum y^{2}}} \\
& =\sqrt{\frac{(1,23849)(842,50)+(1,48082)(786,20)}{6129,00}} \\
& =\sqrt{0,36020} \\
\mathrm{R}_{\mathrm{y}(1,2)} & =\mathbf{0 , 6 0 0 1 7} \\
\mathrm{R}_{\mathrm{y}(1,2)}{ }^{2} & =\mathbf{0 , 3 6 0 2 0}
\end{aligned}
$$

Untuk mengetahui apakah hipotesa mayor yang diajukan diterima/ditolak maka harga R-hitung dibandingkan dengan R-tabel, dan hasil perbandingan Rtabel dengan taraf signifikansi 5\% dengan sampel 100 orang diperoleh $\mathrm{R}$-tabel = 0,195 sedangkan hipotesa mayor $\mathrm{Ry}_{(1,2)}=0,60017$. Dari hasil perbandingan ternyata R-hitung lebih besar dari R-tabel artinya hipotesa kerja (Ha) diterima dan hipotesa nihil (Ho) ditolak, hipotesa kerja yang diterima adalah: "Ada pengaruh gaya belajar siswa terhadap hasil belajar siswa"

Setelah dikonsultasikan dengan tabel interprestasi diatas, maka nilai 0,600 terletak antara $\pm 0,41 \mathrm{~s} / \mathrm{d} \pm 0,60$ berarti pengaruh gaya belajar siswa terhadap hasil belajar adalah pengaruh sedang.

\section{Menghitung Analisis Varian Garis Regresi}

Hasil dari koefisien korelasi di atas perlu di adakan uji signifikansi/guna mengetahui signifikan tidaknya nilai yang diperoleh dua variabel bebas secara serentak dan vareabel dengan rumus sebagai berikut:

$$
\begin{aligned}
\text { F reg } & =\frac{R^{2}(N-m-1)}{m\left(1-R^{2}\right)} \\
& =\frac{0,36020(100-2-1)}{2(1-0,36020)}
\end{aligned}
$$$$
\text { F hitung }=27,30494
$$ 
Dengan $\mathrm{db}=\mathrm{m}$ lawan N-m-1 atau 2 lawan 97 dengan $=0,05 \mathrm{~F}$ tabel $=$ 3,0902 perhitungan di atas F reg sebesar 27,30494 maka F reg > F tabel. Artinya hipotesis antara kriterium $\mathrm{Y}$ dengan prediktor $\mathrm{X}_{1}$ berarti hipotesis nihil (Ho) ditolak dan hipotesis kerja (Ha) di diterima oleh sebab itu dapat dikatakan sinifikansi atau ada pengaruh.

Tabel 1. Perbandingan F-hitung dengan F-tabel

\begin{tabular}{|c|c|c|l|l|}
\hline Hipotesis & Fhitung & $\begin{array}{c}\text { Ftabel } \\
5 \%\end{array}$ & $\begin{array}{c}\text { Keputusan } \\
\text { Statistik }\end{array}$ & $\begin{array}{c}\text { Keputusan } \\
\text { Akhir }\end{array}$ \\
\hline $\mathrm{Ha}$ & 27,30494 & 3,0902 & Signifikan & Diterima \\
\hline
\end{tabular}

\section{Menghitung Efektifitas Garis Regresi (EGR)}

Sumbangan efektif untuk mengetahui besar sumbangan masing-masing variable bebas (prediktor) terhadap variabel terikat (kriterium) yakni sebagai berikut:

$$
\begin{aligned}
\text { JKtotal } & =\sum Y^{2}-\frac{\left(\sum Y\right)^{2}}{N} \\
& =628.650-\frac{(7.890)^{2}}{100} \\
& =\mathbf{6 1 2 9 , 0 0} \\
\text { JK reg } & =\mathrm{a}_{1} \Sigma \mathrm{x}_{1} \mathrm{y}+\mathrm{a}_{2} \Sigma \mathrm{x}_{2} \mathrm{y} \\
& =(1,23849)(842,50)+(1,48082)(786,20) \\
& =1043,42782+1164,22068 \\
& =\mathbf{2 2 0 7 , 6 4 8 5 0} \\
& =\frac{\text { JKreg }}{\text { JKtotal } 100 \%} \\
& =\frac{2.207,64850}{6.129,00} \times 100 \% \\
& =\mathbf{3 6 , 0 1 9 7 2 \%}
\end{aligned}
$$

Dengan demikian dapat diketahui bahwa pengaruh gaya belajar modalitas dan gaya belajar dominasi otak terhadap hasil belajar siswa, sebesar 36,01972\% dan variabel-variabel (faktor lain) yang tidak ikut di teliti sebesar 100\% $36,01972 \%=\mathbf{6 3 , 9 8 8 2 8 \%}$. 


\section{Menghitung Sumbangan Efektif}

Sumbangan efektif digunakan untuk mengetahui besar pengaruh masingmasing variabel bebas (prediktor) terhadap variable terikat (kriterium) yang dilakukan dengan:

\section{a. Sumbangan Efektif $X_{1}$ terhadap $Y$}

$$
\begin{aligned}
\mathrm{SE} \% \mathrm{X}_{1} & =\frac{a_{1} \sum x_{1} y}{J \text { Kreg }} \times E G R \\
& =\frac{(1,23849)(842,50)}{2.207,64850} \times 36,01972 \% \\
& =\mathbf{1 7 , 0 2 4 4 4 \%}
\end{aligned}
$$

\section{b. Sumbangan Efektif $\mathrm{X}_{2}$ terhadap $\mathrm{Y}$}

$$
\begin{aligned}
\mathrm{SE} \% \mathrm{X}_{2} & =\frac{a_{2} \sum x_{2} y}{J K r e g} \times E G R \\
& =\frac{(1,48082)(786,20)}{2207,64850} \times 36,01972 \% \\
& =\mathbf{1 8 , 9 9 5 2 8 \%}
\end{aligned}
$$

Dari hasil perhitungan di atas dapat disimpulkan bahwa sumbangan efektif predictor $\mathrm{X}_{1}$ terhadap kreterium $\mathrm{Y}$ sebesar 17,02444\%, sumbangan efektif predictor $\mathrm{X}_{2}$ terhadap kreterium Y sebeesar 18,99528\%.

Pernyataan diatas menunjukkan bahwa variabel gaya belajar dominasi otak yang paling dominan terhadap hasil belajar siswa. Hal ini terbukti dari proporsi sumbangan gaya belajar dominasi otak yang paling besar $\mathbf{1 8 , 9 9 \%}$ bila dibandingkan variabel gaya belajar modalitas sebesar 17,02 \%. Hasil rekapitulasi data hasil analisa data tertera dalam tabel dibawah ini:

Tabel 2. Hasil analisa data

\begin{tabular}{|c|l|r|r|}
\hline No. & \multicolumn{1}{|c|}{ Variabel Bebas } & EGR (\%) & \multicolumn{2}{|c|}{ SE } \\
\hline 1. & Gaya belajar modalitas & & $\mathbf{1 7 , 0 2}$ \\
2. & Gaya belajar dominasi otak & & $\mathbf{1 8 , 9 9}$ \\
\hline & Jumlah & 36,09 & 36,09 \\
\hline 4. & Variabel bebas lain yang tidak diteliti & $\mathbf{6 3 , 9 1}$ & $\mathbf{6 3 , 9 1}$ \\
\hline & Jumlah & $100 \%$ & $100 \%$ \\
\hline
\end{tabular}

Dari tabel diatas menunjukkan bahwa variabel gaya belajar dominasi otak merupakan variabel yang paling dominan terhadap hasil belajar siswa. Hal ini 
terbukti dari proporsi sumbangan variabel yang paling besar yaitu sebesar 23,30 $\%$.

\section{PENGUJIAN HIPOTESIS}

\section{Pengujian Hipotesis Minor I}

Untuk mengetahui sejauh mana pengaruh gaya belajar modalitas dengan hasil belajar (hipotesa minor) maka dapat dihitung dengan menghitung korelasi antara variabel $\mathrm{X}_{1}$ dan $\mathrm{Y}$ dengan rumus:

$$
\begin{aligned}
r_{\mathrm{y} 1(2)} & =\frac{r y 1-(r y 2)(r 12)}{\sqrt{\left(1-r y_{2}^{2}\right)\left(1-r 12^{2}\right)}} \\
& =\frac{0,48579-(0,50315)(0,35848)}{\sqrt{\left(1-0,50315^{2}\right)\left(1-0,35848^{2}\right)}} \\
& =0,37857
\end{aligned}
$$

Dari analisa data tentang ada tidaknya pengaruh antara gaya belajar modalitas $\left(\mathrm{X}_{1}\right)$ terhadap hasil belajar siswa $(\mathrm{Y})$ diperoleh $\mathrm{r}$ empiric sebesar 0,37857 sedangkan $\mathrm{r}$ table untuk $\mathrm{N}$ sebanyak 100 responden dengan taraf signifikansi 5\% diperleh 0,195 dengan demikian $r$ empiric lebih besar dari tabel, maka hipotesis nihil (Ho) ditolak dan hipotesis kerja (Ha) diterima.

Hal ini berarti ada pengaruh antara gaya belajar modalitas terhadap hasil belajar siswa. Setelah dikonsultasikan dengan tabel interpretasi diatas, maka nilai 0,378 terletak antara $\pm 0,21 \mathrm{~s} / \mathrm{d} \pm 0,40$ berarti pengaruh modalitas $\left(\mathrm{X}_{1}\right)$ dengan hasil belajar siswa adalah pengaruh rendah

\section{Pengujian Hipotesis Minor II}

Untuk mengetahui sejauh mana pengaruh gaya belajar dominasi otak dengan hasil belajar (hipotesa minor kedua) maka dapat dihitung dengan menghitung korelasi antara variabel $\mathrm{X}_{2}$ dan $\mathrm{Y}$ dengan rumus:

$$
\begin{aligned}
r_{\mathrm{y} 2(1)} & =\frac{r y 2-(r y 1)(r 12)}{\sqrt{\left(1-r y_{1}^{2}\right)\left(1-r 12^{2}\right)}} \\
& =\frac{0,50315-(0,48579)(0,35848)}{\sqrt{\left(1-0,48579^{2}\right)\left(1-0,35848^{2}\right)}} \\
& =0,40321
\end{aligned}
$$

Dari analisa data tentang ada tidaknya pengaruh antara gaya belajar dominasi otak $\left(\mathrm{X}_{2}\right)$ terhadap hasil belajar siswa $(\mathrm{Y})$ diperoleh $\mathrm{r}$ empiric sebesar 
0,40321 sedangkan $\mathrm{r}$ table untuk $\mathrm{N}$ sebanyak 100 responden dengan taraf signifikansi 5\% diperleh 0,195 dengan demikian $r$ empiric lebih besar dari tabel, maka hipotesis nihil (Ho) ditolak dan hipotesis kerja (Ha) diterima.

Hal ini berarti ada pengaruh antara gaya belajar dominasi otak terhadap hasil belajar siswa. Setelah dikonsultasikan dengan tabel interpretasi diatas, maka nilai 0,403 terletak antara $\pm 0,41$ s/d $\pm 0,60$ berarti pengaruh gaya belajar modalitas $\left(\mathrm{X}_{2}\right)$ dengan hasil belajar siswa adalah pengaruh sedang. Untuk lebih jelasnya dari hasil seluruh perhitungan mencari besar pengaruh dapat dilihat pada tabel berikut:

Tabel 3. Pengujian Hipotesa Mayor dan Minor

\begin{tabular}{|l|c|c|l|l|}
\hline \multicolumn{1}{|c|}{ Hipotesis } & R.Empirik & R.Tabel & Keputusan & Sumbangan \\
\hline Ha Mayor & 0,600 & 0,195 & Signifikan & $36,09 \%$ \\
Ha Minor 1 & 0,378 & 0,195 & Signifikan & $17,02 \%$ \\
Ha Minor 2 & 0,403 & 0,195 & Signifikan & $18,99 \%$ \\
\hline
\end{tabular}

\section{PEMBAHASAN}

Dari hasil penelitian yang diperoleh dengan menggunakan rumus analisis variansi garis regresi menghasilkan Ry $(1,2)$ empiric sebesar 0,60017. Yang apabila dikonsultasikan dengan $\mathrm{r}$ table dengan $\mathrm{N}$ sebanyak 100 responden dan taraf signifikansi 5\% diperoleh 0,195. perhitungan tersebut dimaksudkan untuk membuktikan hipotesa kerja mayor dengan menggukan uji signifikansi.

Dari hasil perhitungan analisis variansi garis regresi diperoleh $\mathrm{F}_{\text {reg }}$ sebesar 27,30494. Dan apabila dikonsultasikan dengan $\mathrm{F}$ tabel untuk $\mathrm{db}=2 \mathrm{dan} \mathrm{db}=97$ dengan taraf signifikansi 5\% diperoleh 3,0902 Dengan demikian dari hasil perhitungan tersebut menunjukkan $\mathrm{F}$ reg lebih besar dari $\mathrm{F}$ tabel.

Berdasarkan analisa data dimuka, maka hipotesa kerja mayor yang berbunyi "Ada pengaruh gaya belajar siswa terhadap hasil belajar siswa diterima.

Selanjutnya dalam efektifitas garis regresi dipreroleh sebesar 36,01972\%. Ini berarti sumbangan efektif dari keseluruhan predictor hasil belajar siswa memberikan sumbangan sebesar 36,01972\% sedangkan predictor lain yang tidak diteliti memberikan sumbangan sebesar $63,98828 \%$.

Sumbangan Efektif $(\mathrm{SE})$ predictor $\left(\mathrm{X}_{1}\right)$ gaya belajar modalitas terhadap kriterium (Y) hasil belajar siswa 17,02444\%, Sumbangan Efektif (SE) predictor 
$\left(\mathrm{X}_{2}\right)$ gaya belajar dominasi otak terhadap kriterium $(\mathrm{Y})$ hasil belajar siswa $18,99528 \%$, ini menunjukan bahwa gaya belajar dominasi otak lebih berpengaruh terhadap hasil belajar siswa dibandingkan gaya belajar modalitas.

Dengan melihat hasil data yang telah dipaparkan sebelumnya, maka dapat disimpulkan bahwa "Ada pengaruh gaya belajar siswa terhadap hasil belajar siswa kelas".

Dengan demikian dapat dikatakan bahwa siswa akan semakin meningkat hasil belajarnya apabila didukung oleh gaya belajar yang baik selama proses kegiatan pembelajaran, baik dengan memanfaatkan kemampuan modalitas (visual, auditorial, dan kinestik) maupun dengan kemampuan otak yang dimiliki oleh setiap siswa. Menurut Bobbi (2010:111) bahwa Dominasi Otak adalah cara seseorang mengatur serta mengolah informasi. Domisasi adalah tindakan penguasaan terhadap yang lemah sedangkan otak adalah sentral atau pusat saraf. Jadi dominasi otak adalah penguasaan terhadap pusat saraf.

Menurut Gregorc (2010:16) ada hal penting yang perlu diketahui tentang bagaimana anak menangkap pelajaran atau infomasi. Ia membagi fungsi otak dalam menjadi dua macam. Pertama persepsi yaitu cara menerima informasi, kedua Pengaturan yaitu cara menggunakan informasi yang dipersepsikan.

\section{KESIMPULAN}

Berdasarkan hasil penelitian, analisa data dan pengujian hipotesa penulis, maka dapat diambil kesimpulan sebagai berikut :

1. Ada pengaruh gaya belajar siswa terhadap hasil belajar siswa mata pelajaran IPS semester genap di MTs Fathus Salafi Mangaran Kabupaten Situbondo tahun pelajaran 2020/2021 sebesar 0,600 merupakan korelasi sedang.

2. Ada pengaruh gaya belajar modalitas terhadap hasil belajar siswa mata pelajaran IPS semester genap di MTs Fathus Salafi Mangaran Kabupaten Situbondo tahun pelajaran 2020/2021 sebesar 0,378 merupakan korelasi rendah.

3. Ada pengaruh gaya belajar dominasi otak terhadap hasil belajar siswa mata pelajaran IPS semester genap di MTs Fathus Salafi Mangaran 
Kabupaten Situbondo tahun pelajaran 2020/2021 sebesar 0,403 merupakan korelasi sedang.

\section{DAFTAR PUSTAKA}

Ahmadi, Abu.2011. Teknik Belajar Yang Efektif. Jakarta : Rineka Cipta;

Departemen Pendidikan \& Kebudayaan. 2001. Pengembangan Profesional dan Petunjuk Penulisan Karya Ilmiah. Jakarta : Depdikbud RI;

Depdikbud. 2001. Metodologi Pendidikan. Jakarta : Depdikbud RI;

DePorter, Bobbi \& Mike Hernacki. 1999. Quantum Learning. Bandung : Mizan Pustaka;

Hadi, Sutrisno. 2011. Metodologi Reserch Jilid 1, 2, 3, 4. Yogjakarta : Andi;

Hamalik, Oemar. 2013. Proses Belajar Mengajar. Jakarta : Bumi Aksara;

Nasution S. 2013. Berbagai Pendekatan Dalam Proses Belajar Mengajar. Jakarta : Bumi Aksara;

Sanusi, Anwar. 2013. Metodologi Penelitian Praktis Untuk Ilmu Sosial Dan Ekonomi. Jakarta : Buntaba Media;

Slameto. 2011. Evaluasi Pendidikan. Cetakan Ketiga, Jakarta : Bumi Aksara;

Slameto. 2013. Belajar Dan Faktor-Faktor Yang Mempengaruhinya. Jakarta : Rineka Cipta;

Sudjana, Nana dan Ibrahim. 2011. Penelitian dan Penilaian Pendidikan. Bandung : Sinar Baru Algensindo.

Sudjana. 2011. Belajar dan Pembelajaran. Bandung.

Sugiono. 2009. Statistik Untuk Penelitian. Cetakan Ketiga, Jakarta : Alfebita.

Pieta Sahertian, Public School Administration 2. Tahun Edition, New York Ronald Press Co. 1997. Page 642 Grieder et. 